\title{
Pesticide Exposure Levels and Risk Assessment in Operators Involved in the Cashew Production in Côte d'Ivoire
}

\author{
Yao Stéphane Koffi ${ }^{*}$, James Halbin Kouadio', Diakalia Son ${ }^{2}$ \\ ${ }^{1}$ Research Group of Crop Production Quality Management, Laboratory of Agrovalorisation, UFR Agroforesterie, \\ Jean Lorougnon Guédé University, Daloa, Côte d'Ivoire \\ ${ }^{2}$ Agrosystèmes et Ingénierie de l'Environnement (Sy.N.A.I.E), Unité Santé des Plantes du Laboratoire Systèmes Naturels, Institut \\ du Développement Rural (IDR), Université Nazi Boni (UNB), Bobo-Dioulasso, Burkina Faso \\ Email: benzerbo@yahoo.fr, ouakobonzi@yahoo.fr, ireneesomda@yahoo.fr, ‘kystephane.sy@gmail.com
}

How to cite this paper: Koffi, Y.S., Kouadio, J.H. and Son, D. (2022) Pesticide Exposure Levels and Risk Assessment in Operators Involved in the Cashew Production in Côte d'Ivoire. Agricultural Sciences, 13, 86-104. https://doi.org/10.4236/as.2022.131008

Received: November 24, 2021

Accepted: January 27, 2022

Published: January 30, 2022

Copyright (c) 2022 by author(s) and Scientific Research Publishing Inc. This work is licensed under the Creative Commons Attribution-NonCommercial International License (CC BY-NC 4.0). http://creativecommons.org/licenses/by-nc/4.0/ (c) (i) (S) Open Access

\begin{abstract}
To assess the level of producers' exposure and the health risk in relation to phytosanitary practices in cashew crops in Côte d'Ivoire, a descriptive longitudinal toxicological study was conducted in 2018-2019 with 76 cashew producers in the areas of Mankono, Dabakala and Bondoukou. The data collected permitted the assessment of phytosanitary risks on the health of producers according to the Quebec-IRPeQ pesticide risk indicators. Field observations translated into scenarios were used to determine the exposure levels of producers via the UK-POEM predictive model. The main active substances used were glyphosate, 2,4-D, cypermethrin, acetamiprid, lambdacyhalothrin, profenofos, imidacloprid, deltamethrin, mancozeb and metalaxyl. The risk indicators showed that 2,4-D $(\mathrm{TRI}=1332.25$; $\mathrm{SRI}=432.98)$, profenofos $(\mathrm{TRI}=$ 2550.25; SRI $=637.56)$ and mancozeb $(\mathrm{TRI}=841$; $\mathrm{SRI}=147.18)$ among herbicides, insecticides and fungicides respectively could have more adverse health effects after exposure. These findings translated into scenarios specifically showed high exposure of producers to herbicides, with exposure levels ranging from $1.31 \mathrm{mg} / \mathrm{kg}$ bw/day to $1.67 \mathrm{mg} / \mathrm{kg}$ bw/day, well above the acceptable operator's exposure levels (AOEL). These health risks could be significantly reduced if the required personal protective equipment is worn. But, recommended doses of pesticides should be reconsidered, because in some cases, applicators exposure remained high despite the protective equipment.
\end{abstract}

\section{Keywords}

Cashew, Pesticides, Health Risks, UK-POEM, Côte d'Ivoire 


\section{Introduction}

The cashew tree (Anacardium occidentale L.) is a tree native to tropical regions [1]. It is a plant species of significant economic importance worldwide, due to its natural products: the cashew nut (botanically, the fruit) and the pseudofruit (which is actually an extended, fleshy stalk), the cashew apple. Since 2015, Côte d'Ivoire has become the world's biggest producer and exporter of raw cashew nuts. And since then, production volumes have increased considerably year after year, reaching a record production of 900,000 tonnes in the recent 2018-2019 season, which represents almost $24 \%$ of world production [2] [3]. Cashew nut cultivation is mainly concentrated in three major regions of the country, namely the Poro, Hambol and Gontougo regions, where it has now become the main cash crop to diversify farmers' incomes [4].

However, because of pests [5], large orchard areas and insufficient labour, producers are increasingly resorting to phytosanitary treatments to take care of their different cashew plantations [6]. According to [7], the majority of phytosanitary interventions in cashew cultivation in the main production areas are to control weeds and plant pathogens in the crops. However, despite the efficacy of pesticides on pests and their positive effect on the yield increase, their bad use is not without consequences for the health of farmers, consumers or for the environment [8] [9]. At the level of farmers, acute or chronic pesticide intoxications are increasing very considerably worldwide [10] [11] [12]. The situation is most dramatic in African countries, which use only $10 \%$ of the world's pesticides but have over $75 \%$ of fatal intoxications [13] [14]. One of the main reasons for this dramatic situation is related to the poor conditions of pesticide use by African farmers [15] [16] [17]. Moreover, in Africa, data on pesticide poisoning cases are very partial. Most of them come from the Pesticide Action Network (PAN). The data published in 2011 for countries such as South Africa, Senegal, Benin and Mali clearly show that the health consequences of the manipulation of pesticides constitute a real health problem in developing countries [18]. Since then, the links between pesticide use in agriculture in developing countries and producers' health problems have been increasingly studied [16] [17] [19]. And the results are alarming. Indeed, the results show that the exposure levels of producers under real working conditions are extremely high following their phytosanitary practices.

Unfortunately in Côte d'Ivoire, in most agricultural tasks, data on pesticide exposures of producers in real working conditions are scarce, and no agency is responsible for producing them. However, without sufficient knowledge on pesticide exposures in real working conditions, there is no sound risk assessment, either before or after product approval [19] [20]. These unknowns hinder the generalisation of measures to reduce exposures which pose a risk to the health of agricultural workers [20]. Thus, farmers continue to be dangerously exposed, in unknown proportions, in terms of the number of exposed workers and the quantity of exposure. According to the mapping of cashew nut production areas, 
cashew nut producers represent more than almost all Ivorian farmers [2] [4] [6]. The assessment of health risks for these producers, and consequently the adaptation of appropriate protective measures, is therefore necessary to preserve the health of farmers.

It is in this context that this study was conducted in the three major cashew production areas of Côte d'Ivoire. The objective of this work was not only to better characterize the phytosanitary practices of producers, but also to assess the potential risk of phytosanitary practices on their health and the possible exposures to pesticides in real conditions of use.

\section{Material and Methods}

\subsection{Study Sites}

The study was conducted in 19 localities (villages and sub-prefectures) in the departments of Mankono in the northwest, Dabakala in the central-north and Bondoukou in the east of Côte d'Ivoire (Figure 1). These departments represent the three largest cashew growing areas in the country. The choice of these localities also results from the knowledge that they are already known for the use of

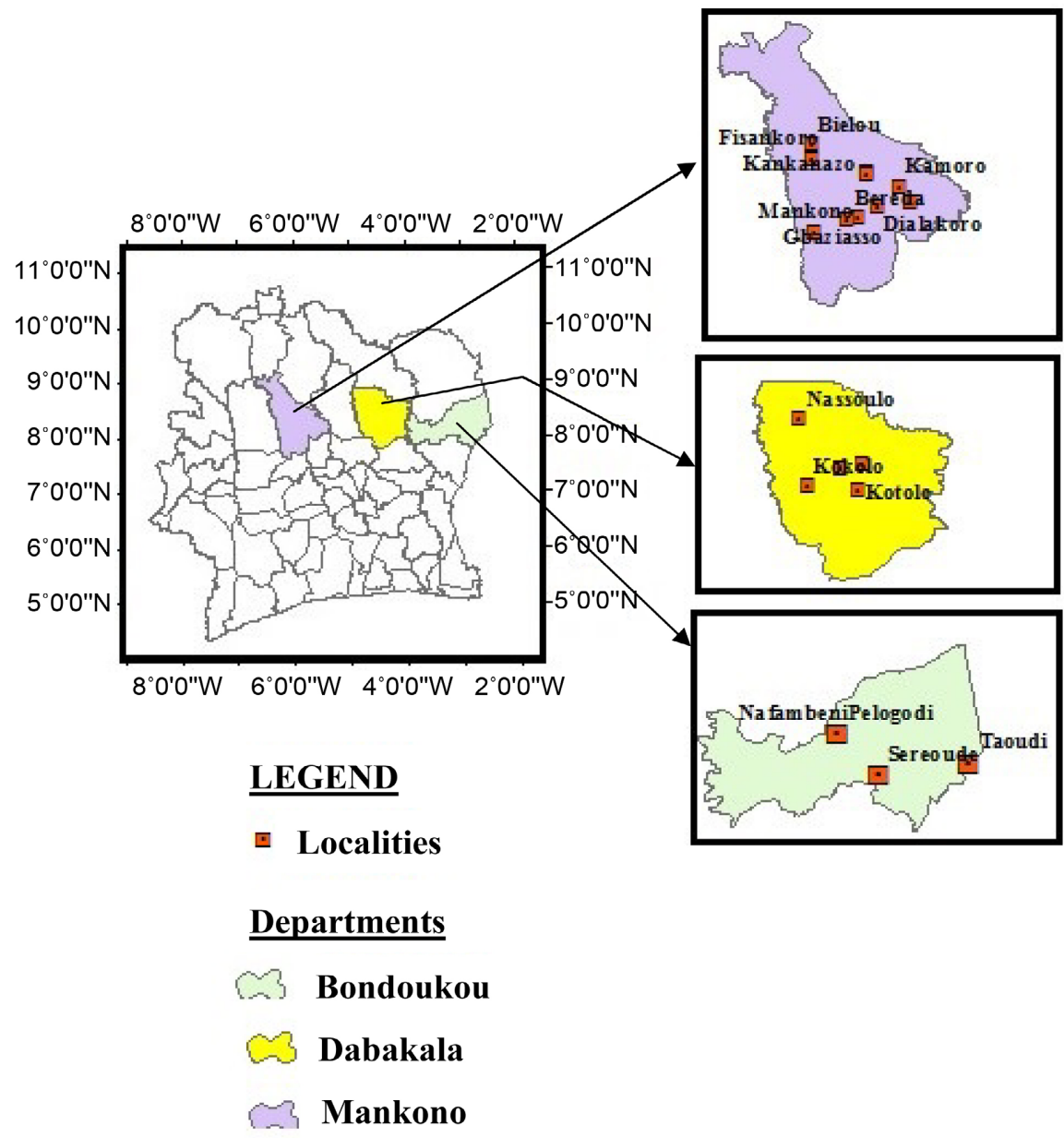

Figure 1. Map showing the different study sites. 
pesticides for the treatment of cashew orchards [7].

\subsection{Survey and Data Collection}

A general survey was first conducted among 386 cashew producers in these cashew production areas during the 2017-2018 agricultural seasons to identify their phytosanitary practices. This first survey was completed by a descriptive longitudinal study in 2018-2019 with 76 producers having at least 5 years of experience in the use of phytosanitary products to assess the risk of phytosanitary practices on their health. These selected producers were among those surveyed in 2017 and 2018 on their phytosanitary practices [7] to follow their phytosanitary practices from start to finish (pesticides used, dosage, personal protective equipment (PPE) worn during treatments, etc.). They were selected based on a random selection of their registration number in the database of producers who participated in the first study.

\subsection{Observations and Measurements}

In order to assess the toxicity of the plant protection products used and the level of exposure of the producers during the application of the pesticides, observations were made as described by [17].

\subsection{Characterisation of the Risk to Health of Producers Associated with Phytosanitary Practices in Cashew Crops}

\subsubsection{Toxicity Risk Index (TRI) of the Active Substances Used}

The Toxicological Risk Index is an indicator that assesses the probability of the active substance affecting certain cellular mechanisms potentially involved in the development of chronic toxic effects. It was calculated using the following Equation as reported by [21].

TRI $=\left[\sum\right.$ of acute toxicity points $+\left(\sum\right.$ of chronic toxicity points $\times$ FPer $\left.)\right]$

With:

FPer $=$ Factor taking into account the environmental persistence, (based on TD50 in soil) or the bioaccumulation potential in humans (BCF value). It ranges from 1 to 2.5 .

To obtain a greater distribution of values and to highlight more the pesticides presenting at higher risk, the sum of the variables was squared and the criteria for acute and chronic toxicity of the active substances are weighted by points [22].

\subsubsection{Health Risk Indexes Plant Protection Products (HRI $I_{P P}$ )}

This index represents the potential risk of an active substance contained in a given trade preparation and according to its use. The Health Risk Index (HRI) was calculated using the Quebec-IRPeQ pesticides risk indicator developed by the Quebec National Institute of Public Health (INSPQ), the Quebec Ministry for Sustainable Development, the Environment and the Parks (MDDEP) and the 
Quebec Ministry for Agriculture, Fisheries and Food (MAPAQ) [22]. This choice was made considering the accessibility of the indicator and its ease of use. It has been used for several studies performed in Benin, Tunisia and Burkina Faso in order to assess and compare the toxicity of various active substances and trade products [17] [19] [23]. The HRI is calculated as follows:

$$
\begin{aligned}
\mathrm{HRI} & =\frac{\mathrm{TRI} \times \mathrm{FP} f \times \mathrm{FCP}}{10} \\
\mathrm{HRI}_{\mathrm{PPP}} & =\sum \mathrm{HRI}_{\text {Active substance }}
\end{aligned}
$$

With:

$\mathrm{HRI}_{\text {Active substance }}=$ Health risk index for the active substance;

FP $f=$ Weighting factor related to formulation type. It ranges from 1 to 2 depending on the potential contamination via the formulation (low risk and high risk respectively);

FCP = Compensation factor to account for the active substance concentration in the end use product and the applied dose (concentration $\times$ recommended dose/ha);

$10=$ Quotient to obtain an HRI of an acceptable order of magnitude, as the value obtained may be very high for some active substances with high TRI.

\subsection{Exposure Assessment of Cashew Nut Producers}

The potential exposure level of producers in $\mathrm{mg} / \mathrm{kg}$ of body weight/day was estimated using the UK Predictive Operator Exposure Model (UK-POEM). This UK predictive model was largely used [16] [17] [23] [24] [25]. The calculation of the Predictive Operator Exposure is made by active substance and for each pesticide. For this study, our working hypotheses on which this assessment was based are presented in Table 1 .

\subsection{Risk Characterization}

The total predictive exposure is the sum of dermal and inhalation exposure during mixing/loading (mainly hand contact) and spraying (droplets received all over the body). The risk for each active substance used by the producers was characterized by comparing the predictive exposure value expressed in $\mathrm{mg} / \mathrm{kg}$ of body weight/day with Acceptable Operator Exposure Level (AOEL). When this value is lower than the value of AOEL, the risk may be considered acceptable. If the risk is considered unacceptable for the market gardener, mitigation measures should be recommended.

\subsection{Collection of Toxicological Data on Listed Pesticides}

The data (dermal LD50, AOEL) and the classification according to the CLP system (Classification, Labelling and Packaging) of the toxicological properties of each active substance were obtained from the European Commission database (EU Pesticides Database, 2020). The SAgE pesticides (Canada), Agritox and 
Table 1. Parameters used in the UK-POEM model to estimate the potential exposure of producers to pesticides.

\begin{tabular}{cc}
\hline $\begin{array}{c}\text { Parameters Used in the } \\
\text { UK-POEM Model }\end{array}$ & Details \\
Application method & $\begin{array}{c}\text { Backpack sprayer (15 L tank) } \\
\text { (which is closer to the sprayer } \\
\text { worn by producers when spraying) }\end{array}$ \\
Formulation type & $\begin{array}{c}\text { Emulsifiable concentrate (EC), Suspension } \\
\text { concentrate (SC) or Wettable powder (WP) }\end{array}$ \\
Absorption through inhalation & $10 \%$ (default value, [26]) \\
Personal Protective Equipment & $100 \%$ (default value, [26]) \\
(PPE) & Scenario 1: none \\
Container & $\begin{array}{c}\text { Scenario 2: With protection } \\
\text { Surface treated/day }\end{array}$ \\
Duration of spraying & 1 L, any closure \\
Operator weight $60 \mathrm{~kg}$ & 1 ha (default value)
\end{tabular}

INERIS (France) databases on agro-pharmaceutical active substances were also consulted.

\subsection{Data Treatment and Statistical Analysis}

After the survey sheets were collected, the data were coded, entered and analyzed using Sphinx 4.5.0.30 and Excel 2010.

Pesticide use in cashew areas was summarized by descriptive statistical analysis (Chi-square test) at the $5 \%$ threshold using SPSS software, and the result was presented as a frequency distribution table.

The determination of the characteristics of the active substances, chemical families and toxicity classes of the pesticides used was established in relation to the names of the pesticides identified using the global lists of homologous and authorised pesticides in Côte d'Ivoire as of 15 March 2018 by the Department of Plant Protection, Control and Quality (DPPCQ) of the Ministry of Agriculture.

\section{Results}

\subsection{Phytosanitary Practices of Producers in Cashew Cultivation}

\subsubsection{Characteristics of Producers in Cashew Cultivation}

The results (Table 2) revealed that cashew producers from Mankono (97.96\%) and from Dabakala (84\%) made extensive use of phytosanitary products in cashew orchards. However, almost all of them had no knowledge of the health risks that these products could cause. The plant protection products most frequently used were, in almost all cases, herbicides (87.20\%). On the other hand, 
Table 2. Characteristics of cashew producers related to the use of plant protection products.

\begin{tabular}{cccccc}
\hline & \multicolumn{5}{c}{ Percentage (\%) by production area } \\
\cline { 2 - 6 } Variables & & $\begin{array}{c}\text { Bondoukou } \\
(\mathrm{n}=114)\end{array}$ & $\begin{array}{c}\text { Dabakala } \\
(\mathrm{n}=125)\end{array}$ & $\begin{array}{c}\text { Mankono } \\
(\mathrm{n}=147)\end{array}$ & Average \\
\hline \multirow{2}{*}{\begin{tabular}{c} 
Use of PPP by producers \\
\cline { 2 - 6 }
\end{tabular}} & Yes & 14.04 & $84.00^{* *}$ & $97.96^{* *}$ & 65.33 \\
\hline $\begin{array}{c}\text { Producers who have } \\
\text { received training on the } \\
\text { toxicological risks of PPP }\end{array}$ & Yes & $85.96^{* *}$ & 16.00 & 2.04 & 34.67 \\
\hline $\begin{array}{c}\text { Types of PPP } \\
\text { used by producers }\end{array}$ & Herbicides & $88.24^{* *}$ & $90.52^{\star *}$ & $82.84^{* *}$ & 87.20 \\
& Insecticides & $11.76^{*}$ & 9,48 & 7.69 & 9.64 \\
\hline
\end{tabular}

$\mathrm{PPP}=$ plant protection products; $(\mathrm{n})=$ number of individuals; $\left({ }^{* *}\right)=$ high correlation between the variable and the locality (significance level of Chi $2<0.05$ and Phi $>0.7$ ); $\left(^{*}\right)=$ low correlation between the variable and the locality (significance level of chi $2<0.05$ and Phi $<0.7)$.

significant use of insecticides was noted in the Bondoukou area.

\subsubsection{Timing of Pesticide Application}

The survey revealed that the timing of pesticide applications in the orchards varied greatly during the day (Figure 2(a)). Pesticide applications were made in morning (6 am - $10 \mathrm{am})$, afternoon (1 pm - $4 \mathrm{pm})$ or (4 pm - $6 \mathrm{pm})$. However, most producers $(46.87 \%)$ preferred morning treatments. This practice was not adopted by a large proportion of producers $(39.35 \%)$ who noted that pesticide treatments were rather dependent on the availability of the applicator. This last observation corroborates the attitude of producers in Bondoukou (Figure 2(b)). Also, according to the results, pesticide treatments in the afternoon (1:00-4:00 p.m.) were often carried out in Mankono area by $10.98 \%$ of producers, unlike producers in Dabakala and Bondoukou.

\subsubsection{Average Doses of Plant Protection Products Applied by Producers}

The results of the survey revealed that the quantities of plant protection products applied per treatment were quite variable (Figure 3). The quantities of herbicides applied varied between 1 and 14 bottles of one litre and between 1 and 50 sachets of one kilogram. The average doses applied were thus estimated to be between 3.2 and 8.2 litres per hectare for liquid formulations and between 1.4 and $2.5 \mathrm{~kg}$ per hectare for solid formulations. For insecticides, there were 1 to 22 boxes per treatment. The average dose applied was thus estimated at 4 litres per hectare in Mankono, 1.8 litres per hectare in Mankono and 0.7 litres per hectare in Bondoukou. The fungicides were only found among producers in Mankono who used 2 to 4 pots (containers) of four litres per treatment. This gave an average dose of 0.5 litres per hectare. Phytosanitary usage in the orchards varied 


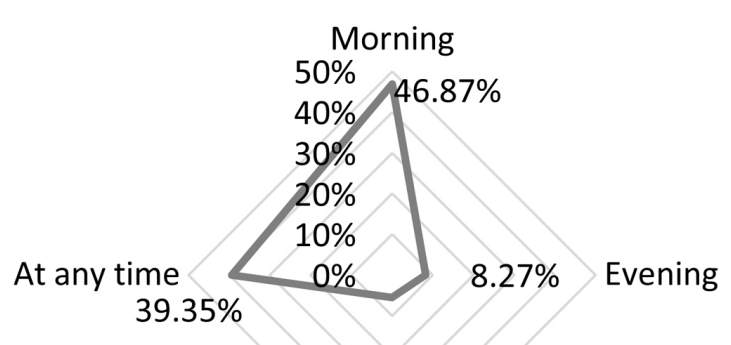

\section{$5.51 \%$}

Afternoon

(a)

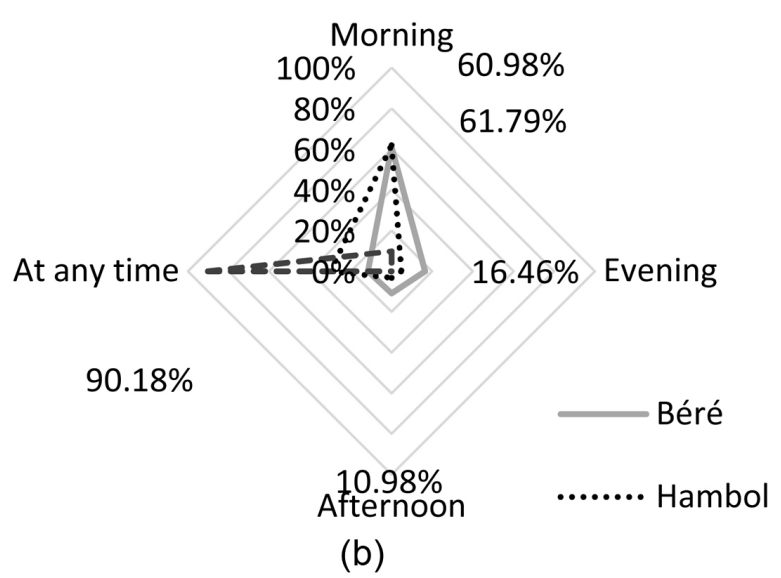

Figure 2. Period of application of pesticides in cashew orchards in general (a) and by production area (b).

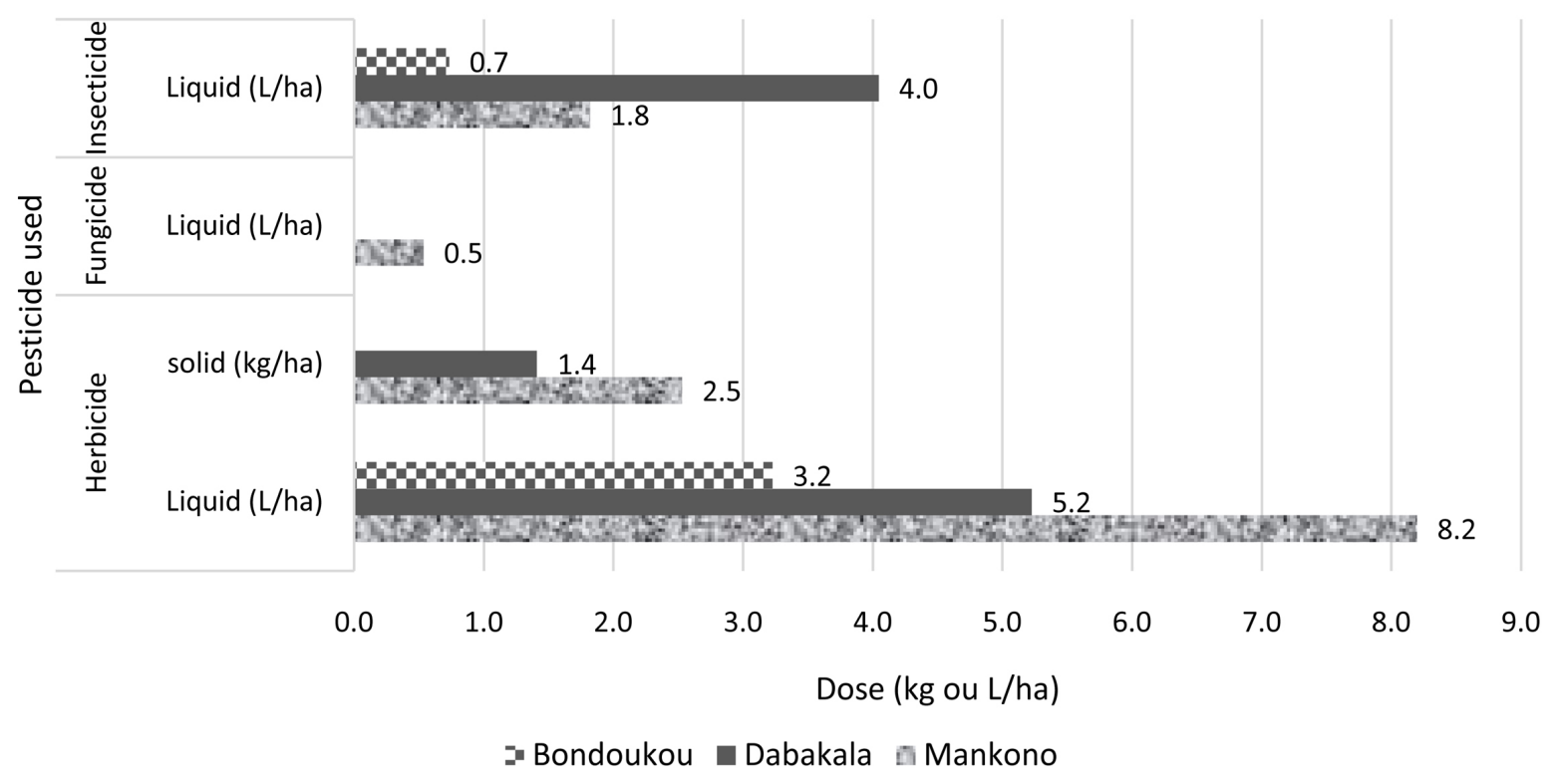

Figure 3. Average quantity of plant protection product applied by producers per hectare and per treatment. The words "solids" and "liquids" refer to the state of the active substance of the formulation. 
according to the frequency of treatment per agricultural year (Table 3 ). In the majority of cases, treatment was carried out twice a year by producers in Mankono (41.7\%) and once by producers in Dabakala (59.8\%) and Bondoukou (43.8\%) to control plant growth. As for insecticides, only producers in the Dabakala area (9.8\%) applied them twice per agricultural year.

\subsection{Health Risks of Pesticides for Producers}

\subsubsection{Most Important Plant Protection Products Used by Cashew Producers}

Our results revealed that various pesticides in different formulations were used by cashew farmers and $50 \%$ of pesticides frequently used were not registered for cashew production in Côte d'Ivoire (Table 4). The plant protection products identified in this study included herbicides, insecticides and fungicides but according to the chemical families of the active ingredients, 6 groups of pesticides have been identified. These were mainly Chlorophenoxyalkanoic Acids, Organophosphates, Carbamates, Phenylamides, Neonicotinoids and Pyrethroids. Furthermore, based on the CLP classification (Classification, Labelling and Packaging of substances and mixtures) of Regulation (EC) No 1272/2008, these active substances are toxic to humans.

Table 3. Plantation treatment frequencies and percentage (\%) of farmers concerned.

\begin{tabular}{ccccccccc}
\hline \multirow{2}{*}{$\begin{array}{c}\text { Number of applications } \\
\text { per agricultural year }\end{array}$} & \multicolumn{2}{c}{ Mankono } & \multicolumn{2}{c}{ Dabakala } & \multicolumn{2}{c}{ Bondoukou } & \multicolumn{2}{c}{ Total } \\
\cline { 2 - 9 } Freq. & $\%$ & Freq. & $\%$ & Freq. & $\%$ & Freq. & $\%$ \\
\hline $\begin{array}{c}\text { Herbicide } \\
1 \text { time }\end{array}$ & 52 & 36.1 & 61 & 59.8 & 7 & 43.8 & 120 & 46 \\
2 times & 60 & 41.7 & 18 & 17.6 & 1 & 6.3 & 79 & 30 \\
3 times & 9 & 6.3 & 3 & 2.9 & 2 & 12.5 & 14 & 5 \\
4 times & 2 & 1.4 & - & - & - & - & 2 & 1 \\
5 times & 1 & 0.7 & - & - & 2 & 12.5 & 3 & 1 \\
Fungicide & & & & & & & & \\
1 time & 1 & 0.7 & 1 & 1.0 & - & - & 2 & 1 \\
2 times & - & - & - & - & - & - & - & - \\
3 times & - & - & - & - & - & - & - & - \\
4 times & - & - & - & - & - & - & - & - \\
5 times & - & - & - & - & - & - & - & - \\
Insecticide & & & & & & & & \\
1 time & 14 & 9.7 & 6 & 5.9 & 3 & 18.8 & 23 & 9 \\
2 times & 3 & 2.1 & 10 & 9.8 & 1 & 6.3 & 14 & 5 \\
3 times & - & - & 3 & 2.9 & - & - & 3 & 1 \\
4 times & 1 & 0.7 & - & - & - & - & 1 & 0.4 \\
5 times & 1 & 0.7 & - & - & - & - & 1 & 0.4 \\
TOTAL & 144 & 100 & 102 & 100 & 16 & 100 & 262 & 100 \\
\hline
\end{tabular}

Freq. = Citation frequency. 
Table 4. Characteristics of plant protection products used in cashew cultivation by producers.

\begin{tabular}{cccccc}
\hline $\begin{array}{c}\text { Trade Name of } \\
\text { PPP used }\end{array}$ & Field of use & $\begin{array}{c}\text { DRA (g ou } \\
\mathrm{ml} / \mathrm{ha})\end{array}$ & $\begin{array}{c}\text { Active Substances } \\
\text { (concentration) }\end{array}$ & Chemical Families & $\begin{array}{c}\text { CLP } \\
\text { Classification }\end{array}$ \\
\hline
\end{tabular}

\section{Herbicide}

Glyphader 360 SL

Ladaba 480 SL

Bibana 680 SG

Possible use in cashew cultivation

Ravage 757 WG

10,000

Glyphosate (360 g/l)

8000

2000

1500

Herbextra 720 SL Rice

1500

2,4 D amine salt (720 g/l)

Glyphosate Isopropylamine

salt $(480 \mathrm{~g} / \mathrm{l})$

Glyphosate (680 g/kg)

Glyphosate (757 g/kg)

Chlorophenoxy-alkanoic acids

H318 (1); H335

(3); H302 (4);

H317 (1)

\section{Fungicide}

Margouza 50 EC Cocoa, Cashew nut 500

\section{Insecticide}

Somon 40 EC

Possible use in cashew cultivation

500

Cocoa, Market

Altes 45 EC gardening

500

Garant extra 40

Cocoa,

EC

Market gardening

500

Lambdacal P 318

EC

Cotton

Polytrine C 336

EC

Cotton

500

Insectido 50 EC Market gardening

500

Dantop 45 SC Cashew nut

500

Avocado, citrus, cocoa, coffee,

Decis 12.5 EC

bananas, market gardening and food crops
Mancozeb $(640 \mathrm{~g} / \mathrm{l})+$
Metalaxyl $(40 \mathrm{~g} / \mathrm{l})$

Cypermethrin $(20 \mathrm{~g} / \mathrm{l})+$

Acetamiprid (20 g/l)

Acetamiprid $(20 \mathrm{~g} / \mathrm{l})+$

Profenofos (25 g/l)

H361d (2);

Carbamate +

H317 (1); H302

Phenylamides

(4); H318 (1)

Pyrethrinoids +

H332 (4); H302

Neonicotinoids

(4); H335 (3)

Neonicotinoids +

Organophosphates

H302 (4);

Lambdacyhalothrin: $20 \mathrm{~g} / \mathrm{l}+$

Pyrethrinoids +

H312 (4); H330

Acetamiprid: $20 \mathrm{~g} / \mathrm{L}$

Neonicotinoids

(2); H301 (3);

H302 (4)

Lambdacyhalothrin $(18 \mathrm{~g} / \mathrm{L})+$

Pyrethrinoids +

H312 (4); H330

Profenofos (300 g/L)

Organophosphates

(2); H301 (3);

Profenofos $(300 \mathrm{~g} / \mathrm{l})+$

Organophosphates +

H332 (4); H302

Cypermethrin (36 g/l)

Pyrethrinoids

(4); H335 (3)

Lambdacyhalothrin $50 \mathrm{~g} / \mathrm{l}$

Pyrethrinoids

H312 (4); H330

Imidacloprid $(30 \mathrm{~g} / \mathrm{L})+$

Neonicotinoids +

(2); H301 (3)

Deltamethrin (15 g/L)

Pyrethrinoids

H331 (3); H301

(3); H302 (4)

Deltamethrin $12.5 \mathrm{~g} / \mathrm{l}$

Pyrethrinoids

H331 (3);

H301 (3)

H301 = Toxic if swallowed; H302 = Harmful if swallowed; H312 = Harmful in contact with skin; H317 = May cause an allergic skin reaction; H318 = Causes serious eye damage; H330 = Fatal if inhaled; H331: toxic by inhalation; H332 = Harmful if inhaled; H335 = May cause respiratory irritation; H361d = Suspected of damaging fertility or the unborn child. The numbers in brackets indicate the hazard categories ( 1 to 4 ) according to the CLP classification. Category 1 is more dangerous than category 4 . The Reference Application dose (RAD) is the maximum dose for a commercial plant protection product formulation in a given crop. 


\subsubsection{Toxicity of Active Substances Used in Cashew Cultivation}

Table 5 presented the Toxicological Risk Index (TRI) of active substances identified which was ranged from 36 to 2550.25. Among the 10 active substances listed, 9 (90\%) of them presented more acute toxicity risk than the chronic toxicity risk. Mancozeb and Lambda-cyhalothrin were both potent acute and chronic toxics. However, mancozeb presented a higher cancer risk than the other active substances. The highest Toxicological Risk Index (TRI) and Health Risk Index (HRI) were obtained with profenofos $(\mathrm{TRI}=2550.25$; HRI $=637.56)$, Lambda-cyhalothrin $($ TRI $=2209$; HRI $=552.25)$ and 2,4-D $($ TRI $=1332.25$; HRI $=$ 432.98) respectively. The lowest TRI and HRI were obtained with Metalaxyl $(\mathrm{TRI}=81 ; \mathrm{HRI}=14.18)$ and Imidacloprid $(\mathrm{TRI}=36 ; \mathrm{HRI}=6.30)$. Profenofos presented not only the highest long-term health risk for the reproduction with high tissue persistence factor but also a higher oral acute toxicity and skin irritation risks. Profenofos was presented in 5 of the most insecticides widely used and registered for cashew cultivation (33.33\% of insecticides). Lambda-cyhalothrin is characterised by high inhalative acute toxicity. Finally, the herbicidal active substance 2,4-D presented also a potent acute skin toxic.

\subsubsection{Toxicity of Trade Formulations Used in Cashew Cultivation}

The toxicity risk index (TRI) and health risk index (HRI) of the plant protection products were determined from the most widely used trade formulation (Table 6) in cashew cultivation in the three study areas. 15 of the trade formulations, or 93.75\%, have a toxicity risk higher than their health risk. Among the trade

Table 5. Toxicity Risk Index (TRI) and Health Risk Index (HRI) of active substances in plant protection products used by cashew producers.

\begin{tabular}{|c|c|c|c|c|c|c|c|c|c|c|c|c|c|c|c|c|}
\hline Active substances & $\begin{array}{l}\text { Oral } \\
\text { tox. }\end{array}$ & $\begin{array}{c}\text { Derm. } \\
\text { tox. }\end{array}$ & $\begin{array}{l}\text { Inh. } \\
\text { tox. }\end{array}$ & $\begin{array}{c}\text { Skin. } \\
\text { ir. }\end{array}$ & $\begin{array}{c}\text { Eye } \\
\text { ir. }\end{array}$ & $\begin{array}{l}\text { Skin } \\
\text { sens. }\end{array}$ & $\begin{array}{l}\text { Acute } \\
\text { tox. }\end{array}$ & Carc & Gen. & EDCs & Repr. & Dev. & $\begin{array}{c}\text { Chron. } \\
\text { Tox. }\end{array}$ & FPer & TRI & HRI \\
\hline Profenofos & 8 & 4 & 4 & 8 & 4 & 0 & 28 & 0 & 1 & 0 & 8 & 0 & 9 & 2.5 & 2550.25 & 637.56 \\
\hline Lambdacyhalothrin & 4 & 4 & 8 & 2 & 1 & 0 & 19 & 4 & 4 & 4 & 0 & 2 & 14 & 2 & 2209 & 552.25 \\
\hline 2,4 D amine salt & 2 & 2 & 2 & 1 & 8 & 8 & 23 & 2 & 0 & 4 & 2 & 1 & 9 & 1.5 & 1332.25 & 432.98 \\
\hline Mancozeb & 1 & 1 & 1 & 1 & 4 & 4 & 12 & 8 & 4 & 4 & 0 & 1 & 17 & 1 & 841 & 147.18 \\
\hline Cypermethrin & 4 & 1 & 2 & 1 & 2 & 8 & 18 & 4 & 0 & 0 & 0 & 0 & 4 & 2 & 676 & 118.30 \\
\hline Deltamethrin & 4 & 4 & 2 & 4 & 4 & 0 & 18 & 0 & 0 & 0 & 0 & 0 & 0 & 1.5 & 324 & 56.70 \\
\hline Glyphosate & 1 & 1 & 2 & 2 & 8 & 0 & 14 & 0 & 0 & 0 & 0 & 0 & 0 & 1 & 196 & 78.40 \\
\hline Acetamiprid & 4 & 1 & 2 & 1 & 1 & 0 & 9 & 0 & 0 & 0 & 2 & 0 & 2 & 1 & 121 & 21.18 \\
\hline Metalaxyl & 2 & 1 & 1 & 1 & 4 & 0 & 9 & 0 & 0 & 0 & 0 & 0 & 0 & 2 & 81 & 14.18 \\
\hline Imidacloprid & 2 & 1 & 1 & 1 & 1 & 0 & 6 & 0 & 0 & 0 & 0 & 0 & 0 & 2.5 & 36 & 6.30 \\
\hline
\end{tabular}

Fper: Factor taking into account the environmental persistence or the bioaccumulation potential in humans; TRI = Toxicological risk index of the active substance; HRI = Health risk index for the active substance; Gen.: Genotoxicity; EDCs: Endocrine disruptive chemicals; Repr.: risk on reproduction; Dev.: risk on development; carc: carcinogenicity; Skin ir.: skin irritation; Eye ir.: Eye irritation; Skin s.: Skin sensitization; Inh tox.: Toxicity by inhalation; Chron. tox.: Chronic toxicity; Derm. tox.: Toxicity by dermal route; Oral tox.: Toxicity by oral route; Acute tox..: acute toxicity. 
Table 6. Toxicity risk index and health risk index of the most frequently used plant protection products by cashew producers.

\begin{tabular}{|c|c|c|c|c|c|c|c|c|}
\hline $\begin{array}{l}\text { Trade Name } \\
\text { of PPP used }\end{array}$ & $\begin{array}{l}\text { Rate of } \\
\text { use (\%) }\end{array}$ & Active substances & $\begin{array}{l}\text { Acute } \\
\text { tox. }\end{array}$ & $\begin{array}{l}\text { Chron. } \\
\text { tox. }\end{array}$ & FPf & FCP & TRI ppp & HRI ppp \\
\hline $\begin{array}{l}\text { Lambdacal P } 318 \\
\text { EC }\end{array}$ & 3.2 & Lambdacyhalothrin + profenofos & 46 & 13 & 2 & 1.25 & 3226.25 & 1189.81 \\
\hline Doni FTE 672 EC & 3.2 & Cypermethrin + profenofos & 28 & 9 & 2 & 0.875 & 2550.25 & 564.59 \\
\hline Hitcel 440 EC & 3.2 & Profenofos + cypermethrin & 37 & 11 & 2 & 0.875 & 2671.25 & 564.59 \\
\hline Polytrine C 336 EC & 9.7 & Profenofos + cypermethrin & 46 & 13 & 2 & 0.875 & 3226.25 & 564.59 \\
\hline Altes $45 \mathrm{EC}$ & 25.8 & Acetamiprid + profenofos & 28 & 16 & 2 & 0.875 & 2330 & 467.47 \\
\hline Fanga 500 & 9.7 & Profenofos & 46 & 13 & 2 & 0.875 & 3226.25 & 446.29 \\
\hline Garant extra $40 \mathrm{EC}$ & 6.5 & Lambdacyhalothrin + acetamiprid & 47 & 23 & 2 & 0.875 & 4759.25 & 407.75 \\
\hline Insectido $50 \mathrm{EC}$ & 9.7 & Lambdacyhalothrin & 19 & 14 & 2 & 0.875 & 2209 & 386.58 \\
\hline Herbextra $^{\circledR}$ & 12.3 & 2,4 D sel d'amine & 14 & 0 & 2 & 1.625 & 196 & 432.98 \\
\hline Margouza 50 EC & 100 & Mancozeb + metalaxyl & 21 & 17 & 2 & 0.875 & 922 & 161.35 \\
\hline Somon $40 \mathrm{EC}$ & 3.2 & Cypermethrin + acetamiprid & 27 & 6 & 2 & 0.875 & 797 & 139.48 \\
\hline Kalach $^{\oplus}$ & 13.5 & Glyphosate & 14 & 0 & 1 à 2 & 2 & 196 & 78.40 \\
\hline Ladaba $^{\oplus}$ & 6.4 & $\begin{array}{l}\text { Glyphosate and Glyphosate } \\
\text { Isopropylamine salt }\end{array}$ & 14 & 0 & 1 à 2 & 2 & 196 & 78.40 \\
\hline Glyphader $^{\circledast}$ & 14.8 & Glyphosate & 14 & 0 & 1 à 2 & 2 & 196 & 78.40 \\
\hline Dantop 45 SC & 3.2 & Imidacloprid + deltamethrin & 24 & 0 & 2 & 0.875 & 360 & 63.00 \\
\hline Decis $12.5 \mathrm{EC}$ & 6.5 & Deltamethrin & 18 & 0 & 2 & 0.875 & 324 & 56.7 \\
\hline
\end{tabular}

Acute tox..: acute toxicity; Chron. tox.: Chronic toxicity; FPf: Weighting factor related to formulation type; FCP: Compensation factor to account for the active substance concentration in the end-use product and the applied dose; TRI ppp: Toxicity Risk Index of plant protection products used; HRI ppp: Health Risk Index of plant protection products used; ${ }^{\bullet}$ Trademark symbol.

formulations, insecticide formulations presented a rather variable health risk from one product to another. Indeed, while the formulation Lambdacal P 318 EC presented the highest risk to human health with an index of 1189.81 , the one named Decis 12.5 EC presented the lowest risk of impact on human health with a HRIppp of 56.7. The fungicide formulation Margouza $50 \mathrm{EC}$ had a health risk level of 161.35. As for the herbicides (Glyphader ${ }^{\oplus}$, Kalach $^{\circledR}$ and Ladaba ${ }^{\circledR}$ ), they generally presented low levels of risk to human health even though a high HRIppp of 432.98 was recorded for the formulations Herbextra ${ }^{\circledR}$.

\subsection{Exposure Level of Cashew Producers in the Three Study Areas}

According to $10 \%$ of skin penetration of the product as authorised by the WHO, our results in Table 7 and Table 8 showed that the applicators were highly exposed to the herbicides used. All active substances applied, even at the recommended rates, presented an unacceptable risk to the operator with an exposure level higher than the Acceptable Operator Exposure Level (AOEL) limits. The highest predictive exposure values during mixing/loading and spraying operations 
Table 7. Potential exposure to cashew producers' herbicides for an unprotected operator.

\begin{tabular}{|c|c|c|c|c|c|c|c|c|c|c|}
\hline \multirow{3}{*}{$\begin{array}{c}\text { Active } \\
\text { substances }\end{array}$} & \multirow{3}{*}{$\begin{array}{c}\mathrm{LD}_{50} \\
(\mathrm{dermal}) \\
(\mathrm{mg} / \mathrm{kg} \\
\text { bw/day) }\end{array}$} & \multicolumn{4}{|c|}{ Operator exposure (mg/kg bw/day) } & \multirow{3}{*}{$\begin{array}{c}\text { AOEL } \\
\text { (mg/kg } \\
\text { bw/day) }\end{array}$} & \multicolumn{4}{|c|}{ Percentage of AOEL (\%) } \\
\hline & & \multirow{2}{*}{$\begin{array}{l}\text { Recommended } \\
\text { dose }\end{array}$} & \multicolumn{3}{|c|}{ Application dose } & & \multirow{2}{*}{$\begin{array}{c}\text { Recommended } \\
\text { dose }\end{array}$} & \multicolumn{3}{|c|}{ Application dose } \\
\hline & & & Mankono & Dabakala & Bondoukou & & & Mankono & Dabakala & Bondoukou \\
\hline $\begin{array}{c}2,4 \mathrm{D} \text { amine } \\
\text { salt }\end{array}$ & $>1829$ & 2.7318 & 17.5529 & 11.1553 & 6.8902 & 0.02 & $13,908.9453$ & $87,764.4063$ & $55,776.4375$ & $34,451.125$ \\
\hline Glyphosate & $>2000$ & 4.0839 & 7.5079 & 4.6522 & 3.8786 & 0.1 & 4176.2579 & 7507.9146 & 4652.1708 & 3878.5556 \\
\hline
\end{tabular}

AOEL: Acceptable Operator Exposure Level; $\mathrm{LD}_{50}$ : is the amount of a single-dose administered at one time that causes the death of $50 \%$ (half) of a group of test animals; $\mathrm{mg} / \mathrm{kg}$ bw/day: milligrams per kilogram of body weight per day.

Table 8. Potential dermal exposure to cashew producers' herbicides for a completely protected operator.

\begin{tabular}{|c|c|c|c|c|c|c|c|c|c|c|}
\hline \multirow{3}{*}{$\begin{array}{c}\text { Active } \\
\text { substances }\end{array}$} & \multirow{3}{*}{$\begin{array}{c}\mathrm{LD}_{50} \\
(\text { dermal) } \\
(\mathrm{mg} / \mathrm{kg} \\
\text { bw/day) }\end{array}$} & \multicolumn{4}{|c|}{ Operator exposure (mg/kg bw/day) } & \multirow{3}{*}{$\begin{array}{c}\text { AOEL } \\
\text { (mg/kg } \\
\text { bw/day) }\end{array}$} & \multicolumn{4}{|c|}{ Percentage of AOEL (\%) } \\
\hline & & \multirow{2}{*}{$\begin{array}{l}\text { Recommended } \\
\text { dose }\end{array}$} & \multicolumn{3}{|c|}{ Application dose } & & \multirow{2}{*}{$\begin{array}{c}\text { Recommended } \\
\text { dose }\end{array}$} & \multicolumn{3}{|c|}{ Application dose } \\
\hline & & & Mankono & Dabakala & Bondoukou & & & Mankono & Dabakala & Bondoukou \\
\hline $\begin{array}{c}2,4 \mathrm{D} \text { amine } \\
\text { salt }\end{array}$ & $>1829$ & 1.3129 & 8.59415 & 5.45115 & 3.35585 & 0.02 & 6564.4561 & $42,970.918$ & $27,255.8985$ & $16,779.2188$ \\
\hline Glyphosate & $>2000$ & 1.6692 & 3.0800 & 1.9404 & 1.8890 & 0.1 & 1431.5950 & 3080.0048 & 1940.4310 & 1889.0278 \\
\hline
\end{tabular}

AOEL: Acceptable Operator Exposure Level; $\mathrm{LD}_{50}$ : is the amount of a single-dose administered at one time that causes the death of $50 \%$ (half) of a group of test animals; $\mathrm{mg} / \mathrm{kg}$ bw/day: milligrams per kilogram of body weight per day.

were observed in Mankono. The values were ranged from 7.5079 (glyphosate) to 17.5529 (2.4 D amine salt) milligrams per kilogram of body weight per day (mg/kg bw/day) without PPE and from 3.08 (glyphosate) to 8.5941 (2.4 D amine salt) $\mathrm{mg} / \mathrm{kg}$ bw/day with PPE worn.

For the insecticides, Table 9 and Table 10 showed that some active substances were safe to use at the recommended application doses. These were acetamiprid, cypermethrin, imidacloprid and metalaxyl. Deltamethrin required PPE before manipulation. Lambda-cyhalothrin was the molecule with the highest potential exposure for cashew producers. It was more than $1000 \%$ with PPE.

Concerning fungicides, only the molecule mancozeb presented a real health risk if used without protection. Indeed, in this condition, the molecule presented, even at the recommended dose, a risk of exposure 21 times higher $(0.752$ $\mathrm{mg} / \mathrm{kg}$ bw/day) than the acceptable threshold limit which is $0.035 \mathrm{mg} / \mathrm{kg}$ bw/day (Table 9).

\section{Discussion}

In our previous study focused on study of pesticides use conditions in cashew production in Côte d'Ivoire, we revealed veritable disparities in pesticides use with poor applicators protection in the three main of cashew nuts production areas namely Bondoukou, Mankono and Dabakala [7]. Several cases of acute intoxication (headache, nausea, etc.) have been reported in $37.6 \%$ of producers who applied pesticides twice in every agricultural year for 2 to $4 \mathrm{~h}$ and in some cases (26\%) within 1 and $4 \mathrm{pm}$ without efficient protection [7]. The present 
Table 9. Potential dermal exposure to insecticides and fungicides of cashew producers for an unprotected operator.

\begin{tabular}{|c|c|c|c|c|c|c|c|c|c|c|}
\hline \multirow{3}{*}{ Active substances } & \multirow{3}{*}{$\begin{array}{c}\mathrm{LD}_{50} \\
\text { (dermal) } \\
\text { (mg/kg } \\
\text { bw/day) }\end{array}$} & \multicolumn{4}{|c|}{ Operator exposure (mg/kg bw/day) } & \multirow{3}{*}{$\begin{array}{c}\text { AOEL } \\
\text { (mg/kg } \\
\text { bw/day) }\end{array}$} & \multicolumn{4}{|c|}{ Percentage of AOEL (\%) } \\
\hline & & \multirow{2}{*}{$\mathrm{RD}$} & \multicolumn{3}{|c|}{ Application dose } & & \multirow{2}{*}{$\mathrm{RD}$} & \multicolumn{3}{|c|}{ Application dose } \\
\hline & & & Mankono & Dabakala & Bondoukou & & & Mankono & Dabakala & Bondoukou \\
\hline Lambdacyhalothrin & 632 & 0.0332 & 0.0575 & 0.0696 & 0.0210 & 0.0006 & 5532.2916 & 9581.4583 & 11606.0417 & 3507.7083 \\
\hline Mancozeb & $>5000$ & 0.752 & 1.3024 & - & - & 0.035 & 2148.5714 & 3721.1429 & & \\
\hline Deltamethrin & $>800$ & 0.0161 & 0.0280 & 0.0339 & 0.0103 & 0.0075 & 215.4167 & 373.0833 & 451.9167 & 136.5833 \\
\hline Acetamiprid & $>2000$ & 0.0235 & 0.0407 & 0.0493 & 0.0149 & 0.025 & 94 & 162.8 & 197.2 & 59.6 \\
\hline Cypermethrin & $>4920$ & 0.0494 & 0.0855 & 0.1035 & 0.0313 & 0.06 & 82.2500 & 142.4500 & 172.5500 & 52.1500 \\
\hline Imidacloprid & $>5000$ & 0.03525 & 0.06105 & 0.07395 & 0.02235 & 0.06 & 58.7499 & 101.7500 & 123.2500 & 37.2500 \\
\hline Metalaxyl & $>3100$ & 0.047 & 0.0814 & - & - & 0.08 & 58.7498 & 101.75 & - & - \\
\hline Profenofos & 472 & 0.3466 & 0.6003 & 0.7272 & 0.2198 & - & - & - & - & - \\
\hline
\end{tabular}

RD: Recommended dose; AOEL: Acceptable Operator Exposure Level; $\mathrm{LD}_{50}$ : is the amount of a single-dose administered at one time that causes the death of $50 \%$ (half) of a group of test animals.; (-) = not available; $\mathrm{mg} / \mathrm{kg}$ bw/day: milligrams per kilogram of body weight per day.

Table 10. Potential dermal exposure to insecticides and fungicides of cashew producers for a completely protected operator.

\begin{tabular}{|c|c|c|c|c|c|c|c|c|c|c|}
\hline \multirow{3}{*}{ Active substances } & \multirow{3}{*}{$\begin{array}{c}\mathrm{LD}_{50} \\
\text { (dermal) } \\
\text { (mg/kg } \\
\text { bw/day) }\end{array}$} & \multicolumn{4}{|c|}{ Operator exposure (mg/kg bw/day) } & \multirow{3}{*}{$\begin{array}{c}\text { AOEL } \\
(\mathrm{mg} / \mathrm{kg} \\
\text { bw/day) }\end{array}$} & \multicolumn{4}{|c|}{ Percentage of AOEL (\%) } \\
\hline & & \multirow{2}{*}{$\mathrm{RD}$} & \multicolumn{3}{|c|}{ Application dose } & & \multirow{2}{*}{$\mathrm{RD}$} & \multicolumn{3}{|c|}{ Application dose } \\
\hline & & & Mankono & Dabakala & Bondoukou & & & Mankono & Dabakala & Bondoukou \\
\hline Lambdacyhalothrin & 632 & 0.0150 & 0.027 & 0.03297 & 0.0090 & 0.0006 & 2510.1302 & 4499.4010 & 5494.0364 & 1515.4948 \\
\hline Mancozeb & $>5000$ & 0.3412 & 0.6116 & - & - & 0.035 & 974.8571 & 1747.4286 & - & - \\
\hline Deltamethrin & $>800$ & 0.0073 & 0.0131 & 0.0160 & 0.0044 & 0.0075 & 97.7396 & 175.1979 & 213.9271 & 59.0104 \\
\hline Acetamiprid & $>2000$ & 0.0107 & 0.0191 & 0.0233 & 0.0064 & 0.025 & 42.65 & 76.45 & 93.35 & 25.75 \\
\hline Cypermethrin & $>4920$ & 0.0224 & 0.0401 & 0.0490 & 0.0135 & 0.06 & 37.3188 & 66.8938 & 81.6813 & 22.5313 \\
\hline Imidacloprid & $>5000$ & 0.0160 & 0.0287 & 0.0350 & 0.0097 & 0.06 & 26.6563 & 47.7812 & 58.3438 & 16.0937 \\
\hline Metalaxyl & $>3100$ & 0.0213 & 0.0382 & - & - & 0.08 & 26.6562 & 47.7812 & - & - \\
\hline Profenofos & 472 & 0.1571 & 0.2819 & 0.3442 & 0.0949 & - & - & - & - & - \\
\hline
\end{tabular}

RD: Recommended dose; AOEL: Acceptable Operator Exposure Level; $\mathrm{LD}_{50}$ : is the amount of a single-dose administered at one time that causes the death of $50 \%$ (half) of a group of test animals.; (-) = not available; $\mathrm{mg} / \mathrm{kg}$ bw/day: milligrams per kilogram of body weight per day.

study, by quantitative analysis of toxicological risk linked to pesticides used in cashew production in Côte d'Ivoire provided data in order to a better understanding or assessment the real exposure levels and consequently the impact of pesticides on the health of farmers. Two models of predictive of toxicological impact of pesticides namely the Quebec-IRPeQ pesticides risk indicator and the UK Predictive Operator Exposure Model (UK-POEM) were used to follow 76 applicators about their pesticide's practices. Theses predictive models were efficient, reliable and largely used in several studies [16] [17] [23] [24] [25] [26]. In parallel, toxicological characteristics of pesticides ingredients or active substances have been collected such as dermal LD50, AOEL and toxicological properties 
data according to CLP system.

As results, critical exposure of applicators by pesticides has been found at Mankono and Dabakala areas. Indeed, the highest predictive exposure values during mixing/loading and spraying operations were observed in these regions Mankono with values ranged from 7.5079 (glyphosate) to 17.5529 (2.4 D amine salt) $\mathrm{mg} / \mathrm{kg}$ bw/day without PPE and from 3.08 (glyphosate) to 8.5941 (2.4 D amine salt) $\mathrm{mg} / \mathrm{kg}$ bw/day with PPE worn. Despite the decreasing of exposure level when applicators were protected, it remained high. Similary, such findings were observed with some incecticides namely acetamiprid, cypermethrin, imidacloprid and metalaxyl. Predictive exposure of applicators was obtained on the basis of only $10 \%$ of dermal absorption from product, the minimal of dermal absorption of pesticide ingredients [26] despite the high relative values of their octanol-water partition coefficient (Kow). The values of logKow of active substances identified in our study were ranged from -3.2 (glyphosate) to 7 (lambdacyhalothrine). However, the lack of safe or protective equipment enhanced to pesticides potential exposure level for cashew producers. For example, with the insecticide Lambda-cyhalothrin, the potential exposure in cashew producers without PPE increased until at $1000 \%$. Similarly, without protection for applicators, the exposure level of the fungicide mancozeb increased namely 21 times higher $(0.752 \mathrm{mg} / \mathrm{kg}$ bw/day) than the acceptable threshold limit which is $0.035 \mathrm{mg} / \mathrm{kg}$ bw/day. Thus, it is very imperious for cashew farmers in Côte d'Ivoire to use pesticides in safe conditions. Indeed, our previous study had been revealed that only $0.4 \%$ of producer applicators were eligible for complete protection [7]. It is also imperious for Ivorian regulatory organism to reconsider the recommended doses of pesticides which remained very high despite the protection of farmers. For example, glyphosate and 1431.6 presented a percentage of AOL of 1431.6 and 6564.5 respectively despite the recommended doses and the complete protection (PPE) of farmers. Those findings supported the previous studies revealing herbicide glyphosate was toxic for the farmers [27] [28]. The insecticides acetamiprid, cypermethrin and imidacloprid were also concerned by similar situation. That supported findings previously reported in Niger and Burkina Faso for tomato producers [16] [17]. It is also important to take a look at the duration of applicators exposure which was long namely ranged from 2 to 6 hours by day during several days according to plantations size, for example, 7 days for a plantation of 10 hectars [7]. However, pesticides exposure could be enhanced in cashew farmers since they used often pesticides packages as gourds and kitchen utensils such as containing salt, milk or oil [7]. Such situation could conduce to a long exposure and consequently chronic intoxication in farmers and their families. Concerning the predictive impact on farmers health, our findings demonstrated by the high TRI (Toxicological Risk Index), the real probability for some actives substances to cause acute toxicity and chronic toxicity such as cancer and reproduction toxicity as previously reported [9] [29] [30]. These actives substances namely Mancozeb, Lambda-cyhalothrin mancozeb Profenofos and herbicide 
2,4-D must be removed in the list of regsitered pesticides in Côte d'Ivoire or in default, Ivorian regulatory organism must be reinforce their safety requirements. Those requirements should be concerned the trade formulations of pesticides used in cashew production in Côte d'Ivoire. Indeed, despite the same composition of active substances, some formulations have been found more hazardous. Thus, while the formulation Lambdacal P 318 EC presented the highest risk to human health with an index (HRI) of 1189.81, the one named Decis 12.5 EC presented the lowest risk of impact on human health with an HRI of 56.7. Similarly, herbicides (Glyphader ${ }^{\circledR}, \mathrm{Kalach}^{\circledR}$ and Ladaba ${ }^{\circledR}$ ) generally presented low levels of HRI even though a high HRI of 432.98 was recorded for the formulations Herbextra ${ }^{\circ}$.

\section{Conclusion}

In conclusion, the present study on the quantitative human exposure of pesticides in cashew production in Côte d'Ivoire revealed that the use of pesticides dramatically poses some concerns in Mankono and Dabakala. The recommended doses of actives substances should be reconsidered following by more exigences on pesticides applicators protection. In addition, there is a lack of culture of risk prevention in the production of cashew nuts in Côte d'Ivoire. Intensive training on safe pesticide use should be performed for producers of cashew nuts in Côte d'Ivoire.

\section{Author Contributions}

Yao Stéphane KOFFI: Methodology, Supervision, Software, Formal Analysis, Resources, Data Retention and Analyses, Research and Acquisition of funding. James Halbin KOUADIO: Project Administration, Conceptualization, Methodology, Resources, Data Retention, Supervision, Writing Original Project, Research and Acquisition of funding. Diakiali SON: Contributed to the analysis of the data.

Institutional Review Board Statement: Ethical review and approval were waived for this first part of the study in lieu of verbal consent of producers. For this study, we used an anonymous questionnaire to ensure the confidentiality of the information collected. However, a dossier has been prepared for the ethics committee for further work. Indeed, we envisage testing biomarkers of exposure and screening pathologies with a medical team.

\section{Funding}

This first part of the study was realized with our personal funds.

\section{Conflicts of Interest}

The authors declare no conflicts of interest regarding the publication of this paper. 


\section{References}

[1] Koffi, Y.S. and Oura, K.R. (2019) Les facteurs de l'adoption de l'anacarde dans le bassin cotonnier de Côte d'Ivoire. Cahiers Agricultures, 28, 24.

[2] Ducroquet, H., Tillie, P., Elouhichi, K. and Gomez, Y.P.S. (2017) L'agriculture de la Côte d'Ivoire à la loupe: Etat des lieux des filières de production végétales et animales et revue des politiques agricoles (JRC107214) [EUR-Scientific and Technical Research Reports]. Publications Office of the European Union, Luxembourg. https://publications.jrc.ec.europa.eu/repository/handle/111111111/51249

[3] Commodafrica (2020) Dans un marché en croissance, l'Afrique contribue à près de $60 \%$ de l'offre mondiale en noix de cajou en 2019.

http://www.commodafrica.com/02-03-2020-dans-un-marche-en-croissance-lafrique -contribue-pres-de-60-de-loffre-mondiale-en-noix-de

[4] MINAGRI (Ministère de l'Agriculture et du développement Rural) and MININDU (Ministère de l'Industrie et des Mines) (2016) Projet d'appui à la compétitivité de la chaîne de valeur de l'anacarde en Côte d'Ivoire: Cadre de Politique de Réinstallation. World Bank Document.

https://ewsdata.rightsindevelopment.org/files/documents/10/WB-P158810 o6DarD j.pdf

[5] N'depo, O.R., Cherif, M., Johnson, F., Kassi, K.F.J.M., N'guessan, A.C., Silue, N., Akesse, E.N., Kone, D. and N'goran, O.M. (2017) Inventaire des insectes ravageurs du verger anacardier dans les régions deBounkani, Gontougo et Indénie-Djablun au Nord-Est en Côte d'Ivoire. Afrique SCIENCE, 13, 333-343.

[6] Ruf, F., Kone, S. and Bebo, B. (2019) Le boom de l'anacarde en Côte d'Ivoire: Transition écologique et sociale des systèmes à base de coton et de cacao. Cahiers Agricultures, 28, 21 .

[7] Yao, S.K., Kouadio, J.H., Yoboue, Y.K.B., Soya, J. and Assanvo E.J. (2020) Study of Pesticides Use Conditions in Cashew Production in Côte d'Ivoire. Journal of Toxicology and Environmental Health Sciences, 12, 1-9.

[8] Coulibaly, S.K., Dicko, H., Camara, B., Diallo, B., Doumbia, D., Soulaymani, A., Maiga, A. and Coulibaly, Y. (2015) Intoxications aiguës aux pesticides: Expérience du Centre Hospitalier Universitaire (CHU) de Point G, Bamako, Mali. Antropo, 34, 69-72.

[9] Boedeker, W., Watts, M., Clausing, P. and Marquez, E. (2020) The Global Distribution of Acute Unintentional Pesticide Poisoning: Estimations Based on a Systematic Review. BMC Public Health, 20, Article No. 1875. https://doi.org/10.1186/s12889-020-09939-0

[10] Baldi, I., Lebailly, P., Jean, S., Rougetet, L., Dulaurent, S. and Marquet, P. (2006) Pesticide Contamination of Workers in Vineyards in France. Journal of Exposure Science \& Environmental Epidemiology, 16, 115-124. https://doi.org/10.1038/sj.jea.7500443

[11] Lebailly, P., Bouchart, V., Baldi, I., Lecluse, Y., Heutte, N., Gislard, A. and Malas, J.P. (2009) Exposure to Pesticides in Open-Field Farming in France. The Annals of Occupational Hygiene, 53, 69-81. https://doi.org/10.1093/annhyg/men072

[12] Toe, A., Ouedraogo, M., Ouedraogo, R., Sylvain, I. and Guissou, P. (2013) Pilot Study on Agricultural Pesticide Poisoning in Burkina Faso. Interdisciplinary Toxicology, 6, 185-191. https://doi.org/10.2478/intox-2013-0027

[13] Cherin, P., Voronska, E., Fraoucene, N. and de Jaeger, C. (2012) Toxicité aiguë des pesticides chez l'homme. Médecine \& Longévité, 4, 68-74. 
https://doi.org/10.1016/j.mlong.2012.05.003

[14] Thiam, A. and Sagna, M.B. (2009) Monitoring des pesticides au niveau des communautés a la base: Rapport Régional Afrique. Dakar, 57 p. http://www.pan-afrique.org/fr/Rapports/Etudes/Rapport Af CBM Fr.pdf

[15] Ahouangninou, C.B.F. and Martin, T. (2011) Evaluation des risques sanitaires et environnementaux des pratiques phytosanitaires des producteurs maraîchers dans la commune rurale de Tori-Bossito (Sud-Bénin). Cahiers Agricultures, 20, 216-222.

[16] Illyassou, K.M., Adamou, R. and Schiffers, B. (2017) Risk Assessment for Small Farmers Exposed to Plant Protection Products in the Niger River Valley. Communications in Agricultural and Applied Biological Sciences, 81, 1-13.

https://orbi.uliege.be/bitstream/2268/212921/1/MassalatchiIllyassou.CommApplBio 1Sci.GhentUniv.2017.pdf

[17] Son, D., Zerbo, F.K.B., Bonzi, S., Schiffers, B., Somda, I., Schiffers, B. and Legreve, A. (2018) Assessment of Tomato (Solanum lycopersicum L.) Producers' Exposure Level to Pesticides, in Kouka and Toussiana (Burkina Faso). International Journal of Environmental Research and Public Health, 15, Article No. 204.

[18] Glynn, A., Thuvander, A., Aune, M., Johannisson, A., Darnerud, P.O., Ronquist, G. and Cnattingius, S. (2008) Immune Cell Counts and Risks of Respiratory Infections among Infants Exposed Pre- and Postnatally to Organochlorine Compounds: A Prospective Study. Environmental Health, 7, Article No. 62. https://doi.org/10.1186/1476-069X-7-62

[19] Gouda, A.I., Toko, I.I., Salami, S.D., Richert, M., Scippo, M.L., Kestemont, P. and Schiffers, B. (2018) Pratiques phytosanitaires et niveau d'exposition aux pesticides des producteurs de coton du nord du Bénin. Cahiers Agricultures, 27, 1-9.

[20] Laurent, C.C., Baldi, I., Bernadac, G., Berthet, A., Colosio, C., Garrigou, A., Grimbuhler, S., Guichard, L., Jas, N., Jouzel, J.N., Lebailly, P., Milhaud, G., Onil, S., Spinosi, J. and Wavresky, P. (2016) Expositions professionnelles aux pesticides en agriculture. Agence Nationale de Sécurité Sanitaire de l'Alimentation, de l'Environnement et du Travail, 96 p. https://hal.archives-ouvertes.fr/hal-01607999

[21] Le bars, M., Mandart, E., Le Grusse, P. and Fabre, J. (2020) Évaluation des risques liés à l'utilisation de pesticides en culture cotonnière au Mali. Cahiers Agricultures, 29, 1-9.

[22] Samuel, O., Dion, S., St-Laurent, L. and April, M.H. (2012) Indicateur de risque des pesticides du Québec: IRPeQ: Santé et environnement. Québec: Québec: Ministère de l'Agriculture, des Pêcheries et de l'Alimentation. Ministère du Développement durable, de l'Environnement et des Parcs. Institut National de Santé Publique du Québec.

https://www.inspq.qc.ca/pdf/publications/1504_IndicRisquesPesticides 2eEdition.p df

[23] Lawson, A.J., Akohou, H.A., Lorge, S. and Schiffers, B. (2017) Three Methods to Assess Levels of Farmers' Exposure to Pesticides in the Urban and Peri-Urban Areas of Northern Benin. Tunisian Journal of Plant Protection, 12, 91-108.

[24] Kim, S.H., Lee, C.H., Kim, K.H. and Jeong, S.H. (2016) Comparative Estimation of Exposure Level and Health Risk Assessment of Highly Produced Pesticides to Agriculture Operators by Using Default Dermal Absorption Rate or Actual Measurement Values. Biomedical Science Letters, 22, 199-206.

https://doi.org/10.15616/BSL.2016.22.4.199

[25] Ouedraogo, R., Makoum, T., Sylvain, I. and Innocent, G. (2014) Risk of Workers Exposure to Pesticides during Mixing/Loading and Supervision of the Application 
in Sugarcane Cultivation in Burkina Faso. International Journal of Environmental Science and Toxicology, 2, 143-151.

[26] WHO (2018) Generic Risk Assessment Model for Indoor and Outdoor Space Spraying of Insecticides-Second Edition.

https://www.who.int/publications-detail-redirect/9789241515054

[27] De Araujo, J.S.A., Delgado, I.F. and Paumgartten, F.J.R. (2016) Glyphosate and Adverse Pregnancy Outcomes, a Systematic Review of Observational Studies. BMC Public Health, 16, Article No. 472. https://doi.org/10.1186/s12889-016-3153-3

[28] Bouagga, A., Chaabane, H., Bahrouni, H. and Hassine, K. (2016) The Use of IRPeQ Model as Indicator to Estimate the Risk of Some Pesticides on Human Health and Environment. Tunisian Journal of Plant Protection, 11, 133-141.

[29] Sánchez-Santed, F., Colomina, M.T. and Herrero Hernández, E. (2016) Organophosphate Pesticide Exposure and Neurodegeneration. Cortex, 74, 417-426. https://doi.org/10.1016/j.cortex.2015.10.003

[30] Kumar, S., Sharma, A. and Kshetrimayum, C. (2019) Environmental \& Occupational Exposure \& Female Reproductive Dysfunction. The Indian Journal of Medical Research, 150, 532-545. 